A. Kobayashi, S. IKUTA : Effects of Anticipation and

\title{
相手チームの力量に対する予測と認知が チームの志気に及ぼす効果
}

$\begin{array}{ccccc}\text { 九 州大学 小 } & \text { 林 } & \text { 篤 } \\ \text { 福岡学芸大学 生 田 清 衡 } & \text { 門 }\end{array}$

\section{I间昌}

末知の相手と試合をする時, 私達は相手の 力量について種々の予測をする。ささて，その 予測が「勝てそうた」という場合と、「勝てそ うるない」という場合とでは，チームの志気 (モラール) はどのように異なるものであろう か.これが第 1 の問題である。

試合が始まる、試合の過程に於て私達は相 手の力量を認知する。この認知が試合前の予 測と一致した場合と一致しない場合とでは， チームの志気はどのように異なるものであろ うか。これが第2の問題である。

試合が終る.試合の過程に於て形成された 志気は，その後の異なつた試合場面まで持続 し，転移されるるのであらうか。これが第 3 の問題である。

本研究は以上 3 つの問題の 解明を目的とし たグループ・ダイナミックスの研究である。

\section{II方法}

対象・種目 - 期间福岡学芸大学坿属袖威 中学校 2, 3 年生. バスケットボール. 1960 年 10 月 7 26日.

チーム檽成 実験チームとして，2 年生男 子 8 チーム, 女子 4 チーム，サクラ・チーム として，男女各 2 チーム。実験チームは 2 チ 一ムすつペアー（対）とするが，各ぺアー・ チームは次の条件をほゔ满足している。

両チームの力量（集団技能の平均値と偏差值 ははが等しい，(2) 顕著に力量（技能）が秀
れる者, 及び劣る者は含まない（3）ハーソ ナリテイに顕著な難点のある者は含まない。 サクラ・チームは 3 年生を中心として， バス ケットボール部員及びその他の運動部員によ つて構成し，その力量は赛験チームよりすぐ れる。

方法〔第】段階】正課体育の時間を利用し て実験チームの試合、試合はペアー・チーム 同士での久行い各 3 試合. 試合時間は前・後 半各 6 分間.

〔第】段階】放課後を利用して実験チームと サクラ (S) チームとの試合. 各 1 試合. ペフ 一トなつている2チームはそれそれ同じ $\mathrm{A}$ 一ムと対戦する。試合前, 実験チームには次 の趣旨の教示を与える.

教示・甲…rS チームはとても強くて, 皆が どんなに碩張つてる到底勝てる相手ではない, 教示・乙…「Sチームは実際は大して強くな く，皆が碩張れば勝てる相手だ」

ペアーとなつているチームには同一の教示 を与える.Sチームに対しては，べーとな つている2チームのうち，1 チームには勝ち， 他の 1 チームには缜汁るように指示する。

〔第四段階〕再び正課体育の時間を利朋して 実験チームの試合. 試合はペアー・チーム同 士でのみ行い, 各 2 試合.

調查测定 (1) 試合に対する熱意, (2) 所 属チームへの満足度, (3) 発言行動の内容, (4) 現実のリーダーと期待のリーダーとの一 致度,をもつて「志気」のメルクマールとし 


\begin{tabular}{|c|c|c|c|c|}
\hline 性 & $\begin{array}{l}\text { 実 } \\
\text { 䶙 } \\
\text { f } \\
1 \\
\text { 出 }\end{array}$ & 教 & $\begin{array}{l}\text { 対 S } \\
\text { 戦子 } \\
\text { すい } \\
\text { るム }\end{array}$ & 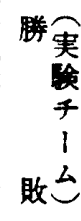 \\
\hline \multirow{4}{*}{ 男 } & $\begin{array}{l}\text { A } \\
\text { B }\end{array}$ & 甲 & $\mathrm{S}_{1}$ & $\begin{array}{l}\text { 勝 } \\
\text { 負 }\end{array}$ \\
\hline & $\begin{array}{l}\mathrm{C} \\
\mathrm{D}\end{array}$ & 乙 & $S_{2}$ & $\begin{array}{l}\text { 勝 } \\
\text { 負 }\end{array}$ \\
\hline & $\begin{array}{l}\mathrm{E} \\
\mathrm{F}\end{array}$ & 甲 & $\mathrm{S}_{1}$ & $\begin{array}{l}\text { 縢 } \\
\text { 角 }\end{array}$ \\
\hline & $\begin{array}{l}\mathrm{G} \\
\mathrm{H}\end{array}$ & z & $\mathrm{S}_{2}$ & $\begin{array}{l}\text { 勝 } \\
\text { 萯 }\end{array}$ \\
\hline \multirow{2}{*}{ 女 } & $\begin{array}{l}\mathrm{K} \\
\mathrm{L}\end{array}$ & 甲 & $\mathrm{S}_{3}$ & $\begin{array}{l}\text { 勝 } \\
\text { 負 }\end{array}$ \\
\hline & $\begin{array}{l}\mathbf{M} \\
\mathrm{N}\end{array}$ & 乙 & $S_{4}$ & $\begin{array}{l}\text { 勝 } \\
\text { 負 }\end{array}$ \\
\hline
\end{tabular}

た。（1）（2）（4）は各試合の前後に質問紙調 查によつて測定し，(3) は観察によつた。但 し, (3) は「活動志向的発言行動」と「批判 的・逃避的発言行動」との比率をるつてメル クマールとする計画であつたが，実際には後 者は殆んどあらわれず，（4）は各チームとも ほ心゙完全に一致しているので，この2つは結 果の分析から除外する.

\section{III 仮設}

\section{A 相手チームのカ目についての予測 と志気との関保}

1.「勝てそうもない」と予测するチーム (教示甲) の志気は低下し，「勝てそうだと 予測主るチーム（教示乙）の志気仙高揚する。

2.「勝てそうもない」と予測する時, 元来 志文の低い者ほど志気は低下する。

3.「勝てそうだ」と予测する時は，元来志 気の高い者も低い者も志気は高揚し, 高揚度 には教がない。

\section{B 相手チームのカ目についての知 と志気との咸係}

1. 予測と認知が一致した場合 I（勝てそ うもない一予测通り強い)…志気は益々低下寸 3.

2. 予測と認知が一致した場合 I（勝てそ うだ一予測通り大して強くないり...志気は益々 高揚する。

3. 予測と認知が一致しない場合 I 勝て そうもない一予測したはど強くない)…志気は 高揚する。

4. 予湘と認知が一致 しない場合 I（勝て そうだ一予測に反して意外に強い)…志気は低 下する。

5. 1 と 4 を比較すれば，志気の低下度は 4 のケースの方が高い。

6，2 と 3 を比較すれば，志気の高揚度は 3 のケースの方が高い。

\section{S チームとの対戦彼の志気の持新 と枟移について}

1. ペフーのうち，S チームに勝つたチー ムは，その後のペアー間の試合に際して，敗 れたチームよりる高い志気を保持し，すぐれ たチーム成績を示す。

2. B. 1 と B. 4 を比較すれば, 志気の低 下度は B. 4 のケースの方が高い。

3. B. 2 と B. 3 を比較すれば，志気の高 揚度は B. 3 のヶースの方が高い。

\section{IV 結 果}

\section{1. 教示の効果}

(表2）サイン・テストによつて1〜3 戦の 平均値と対 $\mathrm{S}$ チームの際の值との差を検定す れば，教示甲を与えたチームではその差はす べて有意，教示乙を与えたチームでは C チー ムのみ有意な差がある。即ち，C を除くすべ てのチームに教示の効果が認められる。但し， 女子チームでは教示の 効果が期待通りである のに反して，教示乙を与えた男子チームの值 は必すしる満足すべき高さには達していない。 
立 2 敗の予㴬勝てそらですか」

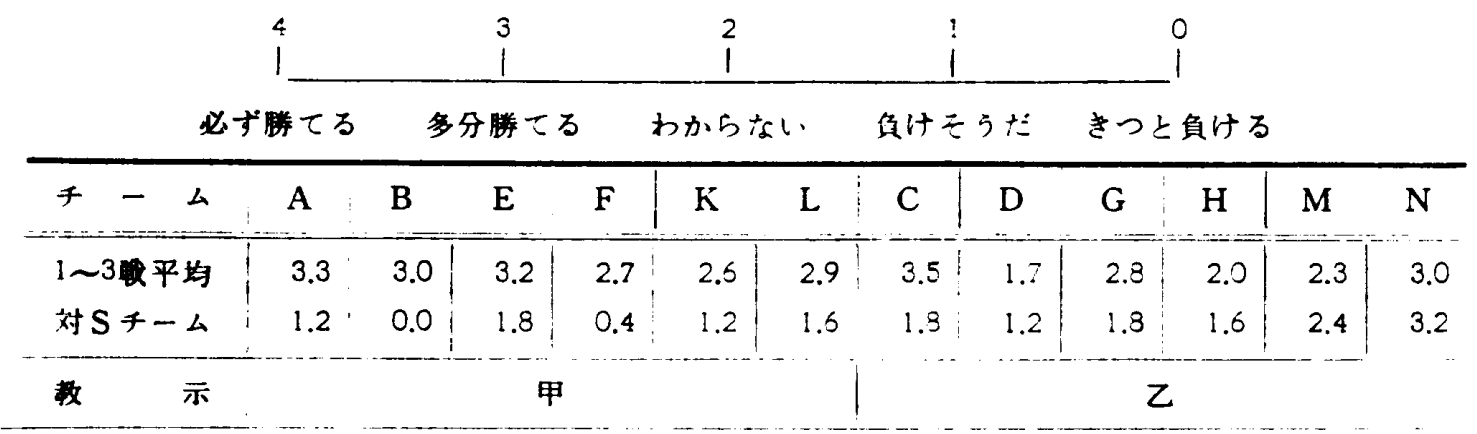

衰 3 S チームとの試合成維

\begin{tabular}{|c|c|c|c|c|c|c|c|c|c|c|c|}
\hline A & B & $\mathrm{E}$ & $\mathbf{F}$ & $\mathrm{K}$ & $\mathbf{L}$ & $\mathrm{C}$ & $\mathrm{D}$ & $\mathrm{G}$ & $\mathrm{H}$ & $\mathbf{M}$ & $\mathrm{N}$ \\
\hline $\begin{array}{c}10 \\
10\end{array}$ & $\begin{array}{c}4 \\
1 \\
24\end{array}$ & $\begin{array}{l}6 \\
1 \\
4\end{array}$ & $\begin{array}{c}10 \\
1 \\
38\end{array}$ & $\begin{array}{l}8 \\
1 \\
4\end{array}$ & $1_{12}^{2}$ & $\begin{array}{c}12 \\
10\end{array}$ & $\begin{array}{c}4 \\
19\end{array}$ & $\begin{array}{c}14 \\
1 \\
12\end{array}$ & $\begin{array}{c}2 \\
1 \\
16\end{array}$ & $\begin{array}{l}6 \\
1 \\
2\end{array}$ & $\begin{array}{l}3 \\
1 \\
2\end{array}$ \\
\hline & & & & & & & & & & & \\
\hline
\end{tabular}

关 4 相手の力量の認知「相手の強さはどうでしたか」

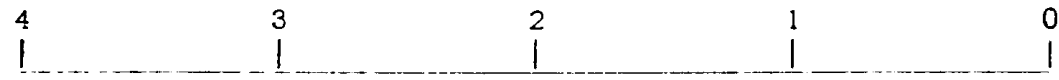

思つていたょり 思つていたより 大体思つて 思つていたより 思つていたより

ずつと强かつた 少し椪かつた いた通り 少し弱かった 思つと弱からた

\begin{tabular}{c|c|c|c|c|c|c|c|c|cc|c|c}
\hline チ - A & A & B & E & F & K & L & C & D & G & H & M & N \\
\hline 平 均 值 & 1.8 & 1.8 & 2.2 & 2.2 & 1.4 & 2.2 & 1.3 & 2.0 & 1.8 & 2.0 & 1.6 & 1.2 \\
\hline
\end{tabular}

（表 3）サクラ・チームのうち， $\mathrm{S}_{4}$ のみ意 外に弱く， $\mathrm{N}$ は接戦してこれに勝つてしまつ

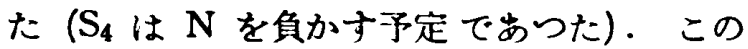
手違いを除いては，他は予定通りの試合成績 である。

（表 4）理論的な期待値からや〉はずれるの は $\mathrm{D}, \mathrm{H}, \mathrm{M}$. かなりはずれるのは $\mathrm{E}, \mathrm{C}, \mathrm{N}$ である。このうち $\mathrm{C} ， \mathrm{~N}$ の 2 チームム予測よ り更に相手が弱かつたというケースで問題は ない.

以上の分析によつて, C, E の 2 チームは教 示の効果が疑わしいことが明らかである。そ こでこの 2 ームは以下の分析から除外する.

\section{2. 仮設 A. 1 の検証}

1 3 戦の平均值と対 $\mathrm{S}$ 戦前の 值との差を 分散分析にかけることにしよう。变動因は教
示甲乙と性別である、結果のみを記せば、「試 合に対する熱意」と「所属チームへの満足度」 は全く同様な結果を示し，男子に扣ける教示 盖と教示甲における性差が有意. 女子に括け る教示差と教示乙における性差は有意でない。 上記の有意差を生した原困は表 5，6にみる如 く，教示甲を与之た男子チーム成員の志気が 著しく低下しているという点にある。一方， 教行乙を与えた男子と教示差に関倸なく女子 では志気は殆んど変化していない，即ち，男 子では，「勝てそうもない」と予測するチーム の志気は顕著に低下するが，「勝てそうだ」と 予測するチームの志気は殆んど变化せす，両 群の志気の変化度には有意な差を生じた。一 方女子では，「勝てそうだ」と予澌するチーム の忘気の变化法男子と同じであるが，「勝てそ 


\begin{tabular}{|c|c|c|c|c|c|c|}
\hline \multicolumn{7}{|c|}{ 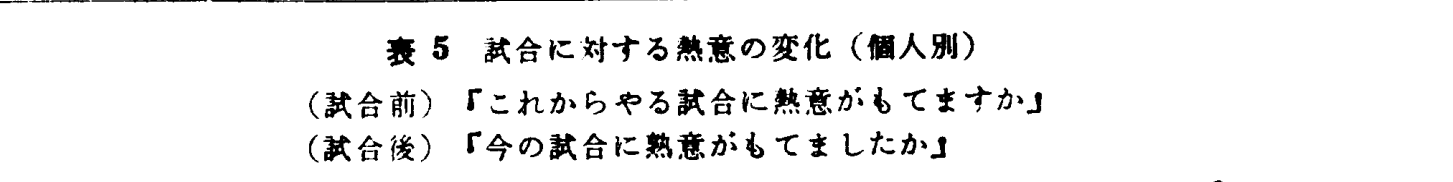 } \\
\hline \multicolumn{2}{|c|}{3} & & $\begin{array}{r}2 \\
1 \\
\end{array}$ & 1 & & 1 \\
\hline \multicolumn{2}{|c|}{$\begin{array}{l}\text { 大いにもてる } \\
\text { (大いにもてた) }\end{array}$} & \multicolumn{2}{|r|}{$\begin{array}{l}\text { かなりもてる } \\
\text { (かなりもてた） }\end{array}$} & （あままりもてない & \multicolumn{2}{|c|}{ （全くしてなない } \\
\hline - 4 & & A & B & $\mathbf{F}$ & $\mathbf{K}$ & $\mathbf{L}$ \\
\hline $1 \sim 3$ 平均 & 2333 & $33(2.7)$ & $22323(2.2)$ & $22223(2.2)$ & $32333(2.8)$ & $33332(2.8)$ \\
\hline 対 $S$ 前 & 2122 & $23(2.0)$ & $11312(1.6)$ & $10113(1.2)$ & $\begin{array}{lllll}3 & 1 & 3 & 3 & 3 \\
(2.6)\end{array}$ & $33333(3.0)$ \\
\hline 前 半 & $\begin{array}{llll}3 & 2 & 3 & 1\end{array}$ & $3(2.4)$ & $31001(1.0)$ & $11323(2.0)$ & $\begin{array}{lllll}3 & 1 & 3 & 3 & 3 \\
(2.6)\end{array}$ & $\begin{array}{lllll}3 & 3 & 3 & 3 & (3.0)\end{array}$ \\
\hline 刘 S 後 半 & $\begin{array}{llll}3 & 3 & 3 & 3\end{array}$ & $31(2.6)$ & $31001(1.0)$ & $12233(2.2)$ & $\begin{array}{lllll}3 & 1 & 3 & 3 & 3\end{array}$ & $33333(3.0)$ \\
\hline 4 戦 & 3233 & $33(2.8)$ & $\begin{array}{llllll}3 & 2 & 1 & 1 & 3 & (2.0)\end{array}$ & $21222(1.8)$ & $\begin{array}{llllll}3 & 1 & 1 & 2 & 1 & (1.8)\end{array}$ & $33333(3.0)$ \\
\hline 于 - 厶 & & D & $\mathrm{G}$ & $\mathrm{H}$ & $\mathbf{M}$ & $\mathbf{N}$ \\
\hline $1 \sim 3$ 戦平均 & 2233 & $32(2.2)$ & $23333(2.7)$ & $22323(2.4)$ & $23333(2.6)$ & $03232(2.0)$ \\
\hline 奶 $S$ 戥 前 & 3132 & $21(2.0)$ & $\begin{array}{llllll}3 & 2 & 3 & 2 & 3 & (2.6)\end{array}$ & $32333(7.8)$ & $12333(2.4)$ & $13233(2.4)$ \\
\hline 前 半 & $3: 31$ & $12(2.0)$ & $\begin{array}{lllll}3 & 3 & 3 & 3 & (3.0)\end{array}$ & $02313(1.8)$ & $23333(2.6)$ & $13333(2.6)$ \\
\hline 付 S 偻 半 & 2132 & $22(2.0)$ & $33333(3.0)$ & $01122(1.2)$ & $33333(3.0)$ & $13233(2.4)$ \\
\hline 4 戦 & 3333 & $32(2.8)$ & $32323(2.6)$ & $32323(2.6)$ & $\begin{array}{llllll}1 & 2 & 3 & 3 & 1 & (2.0)\end{array}$ & $03330(1.8)$ \\
\hline
\end{tabular}

6 所易チームへの满足度（個人别）

「このチームに入つて良かつたと思いますか」

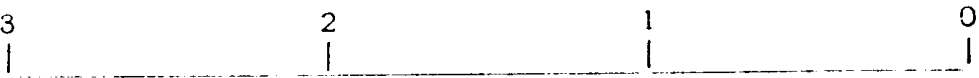

とてもよかつた ああよかつたあまりよくなかつた＼cjkstart全くよくなかつた

\begin{tabular}{|c|c|c|c|c|c|c|c|}
\hline f & & 么 & A & B & F & $\mathbf{K}$ & $\mathbf{L}$ \\
\hline \multicolumn{3}{|c|}{$1 \sim 3$ 戦平均 } & $33333(2.9)$ & $13122(1.4)$ & $22213(1.9)$ & $32333(2.7)$ & $23332(2.7)$ \\
\hline \multirow{2}{*}{\multicolumn{2}{|c|}{ 对 S 戦 }} & 前j & $32333(2.8)$ & $12002(1.0)$ & $21002(1.0)$ & $32333(2.8)$ & $\begin{array}{lllll}3 & 3 & 3 & 2 & (2.8)\end{array}$ \\
\hline & & 媵 & $33333(3.0)$ & $13002(1.2)$ & $21213(1.8)$ & $31333(2.6)$ & $33331(2.6)$ \\
\hline 4 & 戦 & 前 & $32333(2.8)$ & $13012(1.4)$ & $20202(1.2)$ & $32333(3.0)$ & $\begin{array}{llllll}3 & 3 & 3 & 3 & 1 & (2.6)\end{array}$ \\
\hline チ & - & 厶 & $\mathrm{D}$ & G & $\mathrm{H}$ & $\mathbf{M}$ & $\mathbf{N}$ \\
\hline \multicolumn{2}{|c|}{$1 \sim 3$} & 玨 & $32232(2.3)$ & $23333(2.5)$ & $22323(2.4)$ & 33333 & 13332 \\
\hline \multirow{2}{*}{\multicolumn{2}{|c|}{ 奶 S 戦 }} & 前j & $3: 232(2.2)$ & $23333(2.8)$ & $32323(2.6)$ & $33333(3.0)$ & $23332(2.6)$ \\
\hline & & 谣 & $3: 232(2.2)$ & $23333(2.8)$ & $12323(2.2)$ & $33333(3.0)$ & $23332(2.6)$ \\
\hline$\therefore$ & 戦 & 前 & $32233(2.5)$ & $22333(2.6)$ & $12222(1.8)$ & $33333(3.0)$ & $03332(2.1)$ \\
\hline
\end{tabular}

※!〜3戦の均値は小数点以下 4 捨 5 入. 但し分析に際しては小数点以下 1 位までの数値 を用いる。カッュ内はチーム平虰。

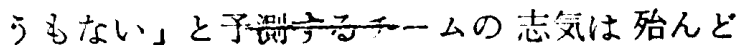
纸下しなかつた。の結果は男子のみ仮設の 前半を立証するが，仮設の後半は男女とる立 证しない.

\section{3. 仮陪 A. 2 の梌低}

教示甲を与えたチーム成員の 志気の变化を $2 \times 2$ 分割表によつて $\chi^{2}$ 検定する . 1 3 戦の 平均值は 2.5 以上，2.5以下に 2 分し，対 $\mathrm{S}$ 
戦前の值は1〜3 戦の平均值に比して高揚した か低下したかによつて+ーに2 分した．1〜3 戦の平均値と対 S 戦前の值が共に 3 である者

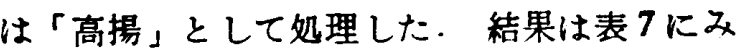
る如く，男子では仮設を立証し，女子すほら゙ 仮設を立証している。

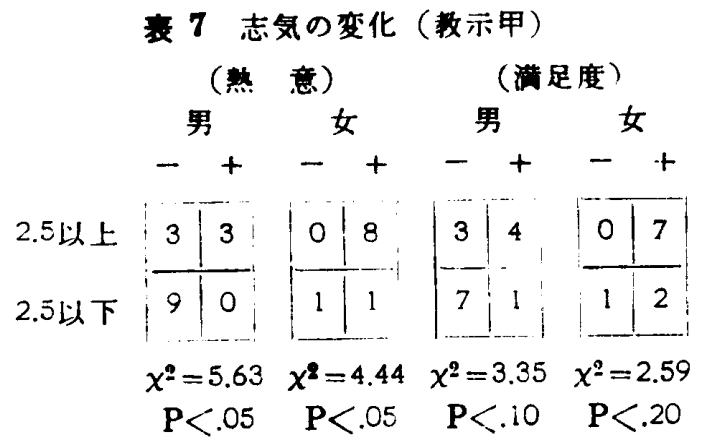

\section{4. 佂设 A. 3 の谓证}

上と同じ方法で数示乙を与えたチーム成員 の志気の変化を検定すれば，表 8 にみる如く 「熱意」「満足度」のいずれに於ても男女とる 分布に有意差は認められない。この結果は仮 設を立証する。

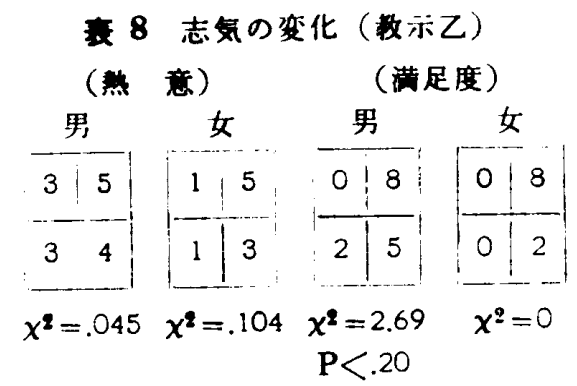

\section{5. 仮数 B の识佂}

対 $\mathrm{S}$ 戦の際の試合前の値と試合前半の值 （表 5，6参照）との差を分析する。女子では 教示乙を与えて S に負けたチームが存在しな いために分散分析を施すことができない，そ こで男子のみ分散分析する．変動因は教示甲 乙と勝敗である。結果のみ記せば，「満足度」 にお汁る負チームの教示差だけが有意である。 即ち，相手に負けたチームのうち、「勝てそう だ」と予測したチーム成員の所属チームムに対
する満足度はや〉低下し、「勝てそうすない」 と予測したチーム成員の満足度はや〉高まり， その間には有意な差を生じた。この結果は仮 設 B. 5 を部分的に立証する。しかしその他 の条件差はすべて有意でない女子では相成 分析を施せば，「熱意」「満足度」とも条件差 はすべて有意でない，即ら，男子における 「満足度」を除いて，仮設はすべて立証されな いそその原因は，敗北を剓したチームの志気 が予期したほど低下せず，中には仮設に反し て志気がや〉高揚 したチームるあつたことに。 求められる。

\section{6. 仮設 $\mathrm{C}$ の模证}

こっでは対サクラ・チーム戦を間に挾んざ ペアー同士の 1〜3 戦と 4 戦前の志気の差が検. 証のためのデータで岕る (表 5，6参照). 男 子については分散分析を施す．变動因は教示 甲乙と対 $\mathrm{S}$ 戦の勝敗である. 結果のみ記せば 有意な差を示したのは「試合に対する 熟意」 のうち負チームにおける教示差だけであつた。 而む負チームのうち教示乙を与えられていた チームの熱意は仮設に反してかなり高揚して いる。つまり，敗北を照したチームのうち， 「勝てそうむない」と予測していたチームの熱 意は低下し、「勝てそうだ」と予測していたチ

关 9 試 合 成

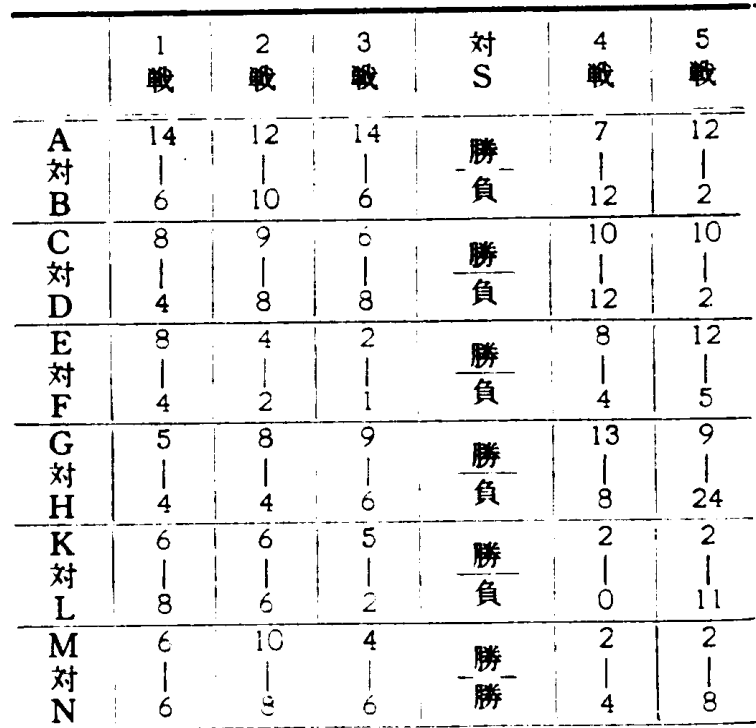


20

一ムの熱意は逆に高揚した。一方女子につい ては相関分析を施せば，「熱意」「满足度」と ๖条件差はすべて有意でない：この結果は仮 没を立証しないまた試合成績についても表 9 にみる如く仮設を立証しない。

\section{$\mathbf{V}$ 結諭}

1.「勝てそうだ」という予測はチームの志 父に顕著な効果は及ぼさなかつた。一方，「勝 てそうるない」という予測がチームの志気に 及ぽマイナスの効果は，男子には顕著であ るが，女子には顕著でなかつた。

2. 「勝てそうむない」と予測子る時, 元来 忑效の低い者ほど一㬝志気が低下した。元の 嚬向は特に男子に著しかつた。

3.「勝てそうだ」と予測する時の志気们変 化は，元来志気の高い者と低い者との間汇差 がなかつた。

4. 相手チームの力量についての試合過程 こおける認知は，チームの志泛顕著な効果 は皮活さなかつた。

う。岕る試合場涌に於て形成されたチーム

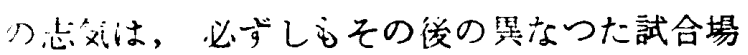
所まで特続し転移するものではなかつた。

\section{VI今啳の問是}

得ら礼た結論を法則化するためには，更に 近試がなされることが必要でらる。グループ ・ダイナミックスの研究は条件統制が困難で 志り，本実駼でる条件が十分に統制されてい るとはいえないのが，その理由の第1で㐫る。 点大仮に条件統制が完全に行わ礼たとしても， 人間の元動や意識は生活環境と切離しては考 シら行ものである以上，クロス・カルチュ ラルな研案が必要で山るというここが，その 䒠由の第2である。

結果の中で特に問題 となるのは，ます第 1 江笙差，第2に相手チームの力量についての 認知と志泡との関係である。

後者についてい党ば，試合過程に於て彼我 のカ舅が違いすぎるということる認知した場
学 研 究

合でも，仮設に反して却つて志気が高揚した チームる山つたのである。なぜあるチームで は志気が低下するのに，山るチームでは志気 が高揚するのであろうか。この問題の追跡は， 抢そらくはスポーッ集団分析の核心に迫るる のとなるであろう。

次に「志気」の測定について，本実験では 基本的には「個人の志気」を合計して「チー ムの志気」とみなす立場をとつた。而も分析 に際しては，個人の次元での分析が混入して いる．碓かに「個人の志気」の合計が「チー 么の志気」と同値であるとは必ずしいいえな い.しかし「集団の志気」そのるのを測定す る技術が未発達である現在では，「個人の志気 の合計」气「チームの志気」という立場をと らざるを得なかつた。また，バスケットボー ルのような小集団では，スコアが正規分布す ることを前提とする差の検定法は使うことが でき文，必然的に個人の次元で分析せさるを 得ない場合がかなり生じた。これらについて る今後の検討を要する。

〔付記〕本研究の実施に际しては，福岡学芸 人学附属福岡中学校教諭梅野公男氏の熱意ある 御協力を得た。亦た実検の為に再三に亘る授亲 時間の入替えに块よく庍じて下さつた他数科の 諸先生，ある時には放課浚遈く迄残つて実検に 纫じてくれた被験者及びサクラ・チームの諸君 に媣く感謝する。

尚本稀では紙幅の闺係から検定の数式，数值 は殆んどすべて省略した。必要とされる向は御 照会をいたよ゙れば幸甚である。

\section{文献}

1) D. Cartwright. A. Zander (1953): Group Dynamics. (邦訳あり)

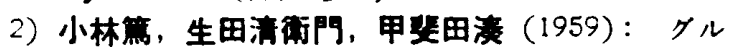
一プ学習におけるグループの形成と人間関係に ついての実呀的研究，第 I報告一所詳チーム・ ワークがチーム成繢に及はす好果一九州大学体 有学研究, 2 巻, 3 号.

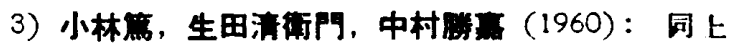
第】報告ーチーム・ゲームにおけるチーム成員 の運娌能力之相互作用の型一九州大学体育学研 然, 2 卷, 4 号。

4) 岩原信九蚛 (1557)：数育と心理のための推計 学. 